\title{
Phenomenological psychopathology in contemporary psychiatry: interfaces and perspectives
}

Melissa G. Tamelini*1 Guilherme P. Messas*2

\begin{abstract}
Due to growing skepticism about the current psychiatric model, psychopathology has once again aroused interest in the psychiatric field. This article intends to examine the current perspectives of the phenomenological approach of psychopathology in the context of psychiatry. To this end, we will situate phenomenology along the historical course of psychopathology, presenting the particularities of its understanding of the psychiatric object, and finally, we will defend, in general terms, the affinity of the phenomenological approach with the aspirations and practical needs of the field of psychiatry.
\end{abstract}

Key words: Phenomenological psychopathology, psychiatry, phenomenological praxis

*1 Universidade de São Paulo - USP (São Paulo, SP, Br).

*2 Faculdade de Ciências Médicas da Santa Casa de São Paulo (São Paulo, SP. Br). 


\section{Introduction}

The plurality of methodological proposals in the field of psychiatry is a direct result of the heterogeneity of conceptions about the "living being called man" (Tellenbach, 1969, p. 9). Throughout time, in the history of psychiatry, different views of psychiatric illness have oscillated regarding their acceptance in culture. In general, a vision aims at establishing a hegemonic relation in regards to the remaining views, determining a prevalent psychiatric model. That was the case, for example, with the move from the organicistic model to the psychoanalytical model in the middle of the twentieth century. The contemporary mainstream psychiatry reveals the hegemony of the neopositivist, neurobiological model. The choice of this model as a synonym for psychiatry has conditioned the orientation of research and the determination of clinical and therapeutic behaviors, especially after the 1980s. In this article, we will examine the consequences of the hegemonic assumption of the neurobiological model in psychiatry; and, later, we will make considerations on the contemporary role and challenges of the phenomenological perspective in psychiatry, based on its particular notion of psychopathology.

\section{Mainstream psychiatry and the decline of psychopathology}

The so-called neurobiological psychiatry - currently dominant - selects neopositivism and logical empiricism (Parnas et al., 2012; Aragona, 2013a) as the "work hypothesis" (Ey, 1969) for the investigation and management of psychiatric conditions. This approach has two central pillars: 1) operationalism (delimitation of "objective" signs and symptoms, with emphasis on the construction of universal and homogeneous diagnostic categories) and 2) biological reductionism (inference of a linear causal correlation 


\section{OBSERVANDO A PSIQUIATRIA}

between the psychic sphere and the cerebral substrate (Araújo \& Banzato, 2014; Parnas et al., 2012). On such bases, mainstream psychiatry has intended to assert itself as a legitimate part of medicine entitled to full rights as a medical specialty.

All psychiatry, as the medical activity that it is, requires the establishment of a psychopathological corpus, since it is necessary to determine the limits of what is pathological so that the medical action can be established. We can say that every conception of psychiatry has its conception of psychopathology, which, in turn, also reveals ambitions of hegemony. In the neopositivist neurobiological psychiatry agenda, the small space reserved for conceptual and methodological discussions led, in fact, to the dilution of the term psychopathology, making it lose its original meaning (Stanghellini, 2009; Parnas et al., 2012). What is considered as psychopathology in the psychiatric mainstream are the formal procedures of operationalism and reductionism, concerned with atomistically describing signs and symptoms guided by arbitrary biological assumptions. In other words, involved with certain objectivity, the discipline of psychopathology has been superimposed, in a clear misunderstanding, to medical semiology (Gorostiza \& Manes, 2011). This misplaced proposal of psychopathology, commonplace in the medical training around the world, emptied itself of notions uncomfortable to its model, among which those of subjectivity and endogeneity (Messas, 2013), and ended up impoverishing the humanistic and conceptual dimension of psychiatry. To the psychiatry for which biology is more important than the fundamental human experience corresponds a psychopathology that is careless with the lived experience and only attentive to behaviors and syndromes.

The prevalence of this model seems to have derived, to a great extent, from the expectations generated around neuroscientific innovations. A herald of a promising future, contemporary psychiatry has centralized its bets on the biological dimension, which should be able to elucidate the pathophysiology of the psychiatric conditions and usher tremendous progress in diagnostic and therapeutic terms. To do so, psychiatry has been based on the simplification of diagnosis, which has led to the establishment of a lingua franca among researchers around the world, while tacitly homogenizing their ways of thinking. The simplification of psychopathology walks pari passu with the rise of the dominant model.

The dominant neopositivist model, however, has been the subject of increasing criticism and its long dominance in the field of psychiatry seems to be threatened (Howard-Jones, 2014; Aragona, 2009, 2013b). The main 


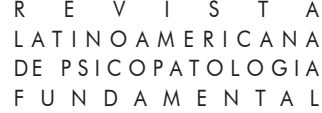

criticisms are directed to its reductionism (subjectivity and consciousness become an epiphenomenon of neuronal brain activity), reification and isolation of the socio-environmental context (Fuchs, 2009). In the same vein, the epistemological project of the Diagnostic and Statistical Manual (DSM) has been the object of reticence regarding many points (Cosgrove \& Krimsky, 2012; Stanghellini \& Aragona, 2016). The range of fragilities of neopositivism is varied and encompasses problems of specificity, reliability, conceptual heterogeneity, excessive presence of comorbidities and tautologies (de Leon, 2015; Aragona, 2009). "Unintentional" effects have been recognized by their own support base (Andreasen, 2007) and, in the DSM series, the fifth and latest (APA, 2013) came amid brand new controversies (Frances, 2013). In this context, the American diagnostic manual shifted from "an icon of scientific psychiatry to a provisional clinical tool" (Zorzanelli et al., 2014, p. 331).

It cannot be said that the character of such criticisms is exactly new. Jaspers $(1989,2000)$ anticipated many of the fallacies of the technological organicistic project in psychiatry ("brain mythology") and, in an analogous position, Straus (1969) warned that the primary object of the psychiatrist's practice was not the brain or organism, but the person in his oneness of 168 individual existence. It follows, therefore, that a psychiatry that seeks to circumvent the fallacies of the neurobiological paradigm and attain individual existence as a whole cannot do without the basic science that is the most connected to life as it is subjectively experienced by people, psychopathology.

\section{Psychopathological science and the phenomenological project}

Crises of models like this are not exactly a novelty in the psychiatric field and have always constituted as a window of opportunity for dissonant paradigms. Faced with the depletion of the DSM agenda and the skepticism with which alternative projects such as the RDoC have been received (Parnas, 2014), elements previously latent in the area have been highlighted: "With DSM emptied of its scientific pretension, the clinical practice, previously underappreciated, becomes its main reason for existence" (Zorzanelli et al., 2014, p. 311). This conception of psychiatry again centered and based on the clinical dimension presupposes the emergence of an alternative epistemological project. The recent resumption of debate on philosophical and methodological assumptions in the area, as well as the remarkable revival of interest in psychopathology shows that this process is already under way 


\section{OBSERVANDO A PSIQUIATRIA}

(Stanghellini \& Aragona, 2016). Psychopathological science is a key point of insertion for a deeper and more reflective clinic to establish itself in psychiatric practice.

We believe that phenomenological psychopathology plays a central role in the gears of this ongoing paradigmatic transformation by allowing psychiatric praxis to be based on more solid foundations (Tamelini \& Messas, 2016). To defend this position, we will present the historical course of psychopathology to better situate its phenomenological approach. Next, we will try to briefly illustrate the viability of a psychiatric praxis of phenomenological orientation, from the diagnostic act to the design of therapeutic guidelines.

Psychopathology is born as a foundational science of psychiatry, with the task of transposing experience of psychic suffering into general and intelligible categories, to be shared as a body of knowledge (Blankenburg, 1983; Minkowski, 2005). There is a relationship of determination and mutuality in the implications between the psychopathological discipline and the psychiatric practice. There is no psychiatry that can ignore at its birth a conceptual understanding of the forms of consciousness that will be characterized as mental pathology. And the detailed characterization of such forms of consciousness, which will be the basis of the different moments of the psychiatric act, is the raison d'être of psychopathology as a science (Pellegrina, 2006; de Leon, 2015). Unlike disease-oriented semiology, his research is directed at the person and the subjective and inter-subjective experience of mental illness (Monti \& Stanghellini, 1996). Three great moments of psychopathological science can be established.

The first moment refers to the work of Jaspers, the pioneer in the preoccupation with the "scientificity of the subjective symptom when, until then, psychiatry only focused on the objective symptom" (Moreira, 2013, p. 124). Its General Psychopathology (2000) proposes to describe psychopathological phenomena and classify them according to their methodological affinities and requirements (Messas, 2014a). Jaspersian descriptive psychopathology opened the psychopathology tradition of the school of Heidelberg (Janzarik et al., 1998) and served as a starting point for the second moment, the so-called clinical psychopathology, which concerned itself with the connection to nosography. In this development, led by Schneider (2007), the major concern is the enucleation of certain phenomena for the composition of a nosological system of classification (Stanghellini \& Aragona, 2016). In this way, in the field of clinical 


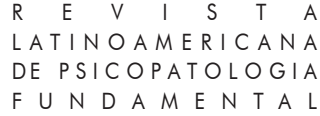

psychopathology, the primacy of the diagnostic act as the purpose of the psychopathological investigation becomes established. However, under the influence of neopositivism, this original Schneider's intention was distorted and detached from its historical basis, simplified into a symptoms checklist that would eventually almost extinguish a whole tradition of knowledge. In a few academic circles, however, a third meaning of psychopathology survived, emancipated from the nosological attributions and requirements of the neurobiological model: phenomenological psychopathology.

This profitable line of investigation must be understood from the evolutionary path of epistemological needs and impasses of the discipline of psychopathology. The original Jaspersian project of a reliable description of psychopathological changes was limited to a particular field of experience. In a natural progression of the discipline, it was crucial to seek an alternative that would allow the psychopathological research project to go ahead (Tamelini \& Messas, 2016). Within this context, psychopathology found in its intimate connections with philosophical anthropology a strategy of continuity.

Philosophical Phenomenology (founded by Husserl and quite heterogeneous in itself), had already aroused interest in Jaspers, although 170 his psychopathology is not strictly phenomenological (Fukuda \& Tamelini, 2016). Husserl's methodological approach to the "return to things themselves," supported by the suspension of theoretical assumptions, aimed at investigating the fundamental constituents of experience or their conditions of possibility, without which a particular experience is not an experience. These basic determinants, as temporality, spatiality, corporeity and inter-subjectivity, known in their totality as the aprioristic structure of consciousness, are particularly visible in altered conditions. The phenomenological psychopathology is precisely dedicated to elucidating the typical alterations of these fundamental structures that will be constituted as specific psychopathological frameworks (Fuchs, 2010). Given this focus, since its official inauguration in 1922, phenomenological psychopathology has been seen as the most consistent attempt to illuminate the ontological ground of psychiatry (Rovaletti, 2016). Thus, in addition to a simple new psychopathological current, the phenomenological qualifier indicates the natural progression of the research agenda of psychopathology and inaugurates a moment of greater maturity of psychopathology as a science (Stanghellini, 2009).

The incorporation of phenomenology into psychopathology gave psychopathology a rigorous scientific status outside the realms of the natural 


\section{OBSERVANDO A PSIQUIATRIA}

sciences (Binswanger, 1973). The phenomenological contribution has brought innovative tools for the exploration of the psychopathological phenomena, thus becoming a lasting and perennial necessity of psychiatry (Morley, 2002). The expansion of the object of study from pathological experience to its aprioristic dimension extended the scope of psychopathological understanding (Fuchs, 2013; Blankenburg, 2013). This advance can be exemplified paradigmatically with the delusional phenomenon. It is only under phenomenological appreciation that delusion can be revealed in its specificity, that is, as a rupture of the intersubjective presuppositions of consciousness that are determinant to what we experience as reality (Tamelini \& Messas, 2016). Delusion, therefore, for phenomenological psychopathology, is not only a matter of alteration of experiential content, but, above all, of modification of the conditions of possibility in which all experience is inserted. The scientific recognition of how experience is manifested is more important and more elucidative than the description and reporting of its content.

Today, the sophisticated body of knowledge of this psychopathology has once again aroused interest, stimulated by the inconsistencies of neurobiological psychiatry. In the work of authors like Minkowski, Binswanger, Gebsattel, Tellenbach and Blankenburg are again being rediscovered the methodological foundations of an ambitious and complex project of understanding of the most distinct psychopathological experiences, which recovers its anthropological meaning as a human possibility (Minkowski, 2005). The phenomenological program returned to focus at a time when psychiatry is compelled to reflect on its own foundations and clinical practice. And, within such needs, phenomenology is in a "unique position" in the field (Parnas \& Zahavi, 2002), and can contribute with the same competence in conceptual, diagnostic and therapeutic discussions.

\section{Elements of a psychiatric praxis of phenomenological orientation}

Given the above, psychopathological science is nowadays not only entrusted with retaking historical conceptions of mental pathology but also expanding and modernizing them for clinical and co-operative purposes (Stanghellini \& Broome, 2014). In relation to practical purposes, phenomenology is incorporated into the psychopathological field in close connection with the intersubjective dimension of the clinic. Within its 


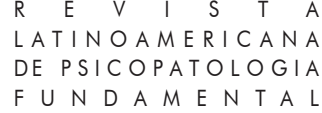

tradition, it is emphasized that the psychopathological knowledge is born and is based on the in-depth experience of the contact with the patient. It will be in the midst of the uniqueness of the clinical case that phenomenological psychopathology will deal with pathology in its universal anthropological dimension (Messas, 2014b). It is within the aforementioned aprioristic coordinates that, in fact, different symptomatic presentations of a different structural order will be differentiated. For example, classical melancholy and a depressive picture of a reactive nature will be seen and consequently approached clinically, as radically different conditions, although there is semiological overlap between them. Although they may, semiologically, confuse themselves, melancholia and reactive depression are based differently on existence. The first derives from an excessive subordination of personality to social norms (Tellenbach, 1979); the second, more indeterminate, can arise, for example, from the loss of support for the self in a very valuable interpersonal relationship (in the case of mourning).

In the same way, phenomenology will proceed in relation to diverse pathologies such as schizophrenia, mania, and melancholy, specifying the time-spatial, corporeality and inter-subjectivity characteristics that determine 172 the appearance of such clinical entities. This dimension of experience addressed by the phenomenologist is captured by an act of "empathic penetration" (Minkowski, 2005), that is, by the intuitive apprehension of consciousness as a totality (Messas, 2004). This "psychopathology in two voices" not only does not exclude the understanding of the particularities of individuals as it allows the recognition of the pathology in its universality.

Coherently with its mode of establishment of diagnosis, phenomenological therapy will propose intervention strategies based on the findings of its investigation. Returning to the difference above between melancholia and reactive depression, we will have, for example, that melancholy requires a therapy that allows the personality to return to its previous social roles. A reactive depression, on the other hand, has as therapeutic objective the reformulation of the interpersonal relations.

With this step, we move from phenomenological psychopathology to phenomenological psychiatry. As phenomenological psychopathology understands pathology as the imposition of a typical alteration in the structural substrate of consciousness, pharmacological and psychological therapy (for psychiatric phenomenology, it does not make much sense to distinguish between pharmacotherapy and psychotherapy) should take into account the impact of those therapeutic proposals in this fundamental dimension of experience. 


\section{OBSERVANDO A PSIQUIATRIA}

It is, therefore, a unified and complex conception of treatment. However, there are still few studies in the literature that specify and detail such treatment orientation, in contrast to the volume of work related to diagnostic issues. Thus, the establishment of phenomenological guidelines in the treatment of mental disorders still requires greater support in the literature and more studies. However, this does not mean that this type of approach is a novelty. It has already been postulated that a "weak" variant of the phenomenological position is adopted in the daily routine of the clinic (Parnas et al., 2011), that is, although implicitly, experienced clinicians would use several phenomenological assumptions in the elaboration of their diagnostics and proposals of treatment. Faced with the distance between the positivist explanatory models and their clinical practice (Morley, 2002) and the observation of a considerable gap between their clinical application and the treatment guidelines from neurobiological psychiatry (Girlanda et al., 2017), many precepts of a phenomenological nature are put into practice daily, albeit in an unintentional or unknowing way (Parnas et al., 2011).

However, it is crucial to psychiatry that this "weak" variant of phenomenological praxis may become explicit to clinicians. The maintenance of phenomenological precepts implicitly reduces their scientific status and ends up considering them to be unscientific. The exclusion of phenomenology - as well as of other disciplines that aim at understanding subjective experiences - of psychiatric scientificity banishes the most necessary element for the promotion of mental health. The production of mental health is a practical purpose, and psychopathological science is the deeper instrument for the exercise of this task. For the full participation of phenomenology in psychiatry, it is necessary that larger numbers of experienced psychiatrists as well as psychiatrists in training become aware of this concrete alternative of validating clinical experience and address practical reference matters to it. Since phenomenological psychopathology is the consolidation of decades of reflexive and empathic experiences with patients, there is no reasonable justification for not exercising it in clinical practice. In this way, it is quite feasible that, at this moment especially conducive to the reformulation of the conceptual foundations of psychiatry, we can, finally, have the definitive and comprehensive strengthening of phenomenology in the field of psychiatry.

Moreover, if phenomenology can illuminate the clinical dimension, it may also be key to understanding the biological dimension. The modern conception of phenomenological psychopathology does not abandon the idea of a compatibility with the program of neurosciences. On the contrary, 


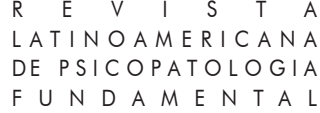

if psychiatry can refine its psychopathological concepts and better delimit clinical species, we will certainly have more consistent biological research hypotheses (Fuchs, 2009). Some authors even attribute to the recent impoverishment of psychopathology the failure of ambitions in genetic and neuroimaging research, as if the biological research program of psychiatry were in some blind spot in its field, operating without rigorously validated methodological positions (Fuchs, 2002; Parnas et al., 2012). On the other hand, it would be regrettable if the great power of phenomenology were neglected in favor of secondary utility, as a "mere appendage" of neurosciences (Morley, 2002). In this sense, phenomenology must be embraced for its contribution to the legitimacy of the biological research program, constituting an alternative to the currently dominant epistemological orientation in the field of psychiatry (Messas, 2010).

\section{Conclusions}

The phenomenological paradigm can assume a central role in the contemporary psychiatric scenario. Phenomenology presents all the conditions to be the "working hypothesis" of a resumption of psychiatry on more complex bases. Above all, since its incorporation into psychopathology in the 1920s, phenomenology has been the vigorous antithesis of reductive tendencies in the field. Due to a conception that is coherent with the complexity of the psychiatric object, it has been shown to be of particular importance in several points of psychiatric practice.

The perspectives for the development of phenomenology as the center of psychiatric praxis require the extensive cooperation of the scientific community and much defense in literature. The immediate challenge of phenomenology in current psychiatry is the intellectual aid to overcoming the narrow biological view of the patient and the resumption of the historically established humanist tradition in the field. On the less immediate plane, we believe its methodological support to psychiatry in all its acts and purposes is feasible, based mainly on the expansion of phenomenological psychopathology to other psychopathological experiences yet not explored.

Thus, we believe that what is at stake in the present scenario is not only the resumption of the emphasis on psychopathological research but the broad integration of phenomenology with psychiatric praxis as a whole. Especially attuned with current aspirations for change, the phenomenological position 


\section{OBSERVANDO A PSIQUIATRIA}

returns fundamental values to the field, and its future developments may consolidate modern psychiatry as a practice that combines a strong humanist appeal to the technological apparatus.

\section{References}

American Psychiatric Association. (2013). Diagnostic and statistical manual of mental disorders (DSM-5®). American Psychiatric Pub.

Andreasen, N. C. (2007). DSM and the death of phenomenology in America: an example of unintended consequences. Schizophrenia bulletin, 33(1), 108-112.

Aragona, M. (2009). The role of comorbidity in the crisis of the current psychiatric classification system. Philosophy, Psychiatry, \& Psychology, 16(1), 1-11.

Aragona, M. (2013a). Neopositivism and the DSM psychiatric classification. An epistemological history. Part 1: Theoretical comparison. History of psychiatry, 24(2), 166-179.

Aragona, M. (2013b). Neopositivism and the DSM psychiatric classification. An epistemological history. Part 2: Historical pathways, epistemological developments and present-day needs. History of psychiatry, 24(4), 415-426.

Araújo, L. F. S. C. de; Banzato, C. E. M. (2014, março). Causas "fracas" e redes causais complexas em psiquiatria. Revista Latinoamericana de Psicopatologia Fundamental, 17(1), 15-28.

Binswanger, L. (1973). Sobre Fenomenologia. Artículos y conferencias escogidas. Madrid: Editorial Gredos.

Blankenburg, W. (1983). La psicopatología como ciencia básica de la psiquiatría. Revista chilena de Neuropsiquiatría, XXI, 177-188.

Blankenburg, W. (2013). La pérdida de la evidencia natural. Una contribución a la psicopatología de la esquizofrenia. Santiago de Chile: Ediciones Universidad Diego Portales.

Cosgrove, L., Krimsky, S. (2012). A comparison of DSM-IV and DSM-5 panel members' financial associations with industry: A pernicious problem persists. PLoS Med, 9(3), e1001190.

de Leon J. (2015). Is psychiatry only neurology? Or only abnormal psychology? Déjà vu after 100 years. Acta Neuropsychiatrica, 69-81.

Ey, H. (1969). Outline of an organo-dynamic conception of the structure, nosography, and pathogenesis of mental diseases. Psychiatry and Philosophy (pp. 111-161). Springer Berlin Heidelberg. 


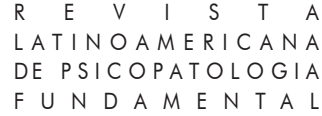

Frances, A. (2013). Saving normal: An insider's revolt against out-of-control psychiatric diagnosis, DSM-5, big pharma and the medicalization of ordinary life. Psychotherapy in Australia, 19(3), 14.

Fuchs, T. (2002) The challenge of neuroscience: Psychiatry and phenomenology today. Psychopathology, 35, 319-326.

Fuchs, T. (2009). Embodied cognitive neuroscience and its consequences for psychiatry. Poiesis \& Praxis, 6(3-4), 219-233.

Fuchs, T. (2010). Phenomenology and psychopathology. In Handbook of phenomenology and cognitive science (pp. 546-573). Springer Netherlands.

Fuchs, T. (2013). Temporality and psychopathology. Phenomenology and the cognitive sciences, 12(1), 75-104. DOI 10.1007/s11097-010-9189-4.

Fukuda, L. E., \& Tamelini, M. G. (2016). A compreensão psicológica jasperiana revisitada sob a perspectiva da psicopatologia fenomenológica. Psicopatologia Fenomenológica Contemporânea, 5(2), 160-184.

Girlanda, F., Fiedler, I., Becker, T., Barbui, C., \& Koesters, M. (2017). The evidencepractice gap in specialist mental healthcare: systematic review and meta-analysis of guideline implementation studies. The British Journal of Psychiatry, 210(1), 24-30.

176 Gorostiza, P. R., \& Manes, J. A. (2011). Misunderstanding psychopathology as medical semiology: An epistemological enquiry. Psychopathology 44, 205-215.

Howard-Jones, P. A. (2014). Neuroscience and education: myths and messages. Nature Reviews Neuroscience, 15(12), 817-824.

Janzarik, W., Viviani, R., \& Berrios, G. E. (1998). Jaspers, Kurt Schneider and the Heidelberg school of psychiatry. History of psychiatry, 9(34), 241-252.

Jaspers, K. (1989). The physician in the technological age. Theoretical Medicine and Bioethics, 10(3), 251-267.

Jaspers, K. (2000). Psicopatologia geral. São Paulo, SP: Atheneu.

Messas, G. P. (2004). Psicopatologia e transformação: um esboço fenômenoestrutural. São Paulo, SP: Casa do Psicólogo.

Messas G. P (2010). A phenomenological contribution to the approach of biological psychiatry. Journal of Phenomenological Psychiatry, 41, 180-200.

Messas, G. P (2013). Sentido e limites do diagnóstico diferencial entre psicoses endógenas e exógenas. Psicopatologia Fenomenológica Contemporânea, 2(1), 2-15.

Messas, G. (2014a). O sentido da fenomenologia na Psicopatologia Geral de Karl Jaspers. Psicopatologia Fenomenológica Contemporânea, 3(1), 23-47.

Messas, G. (2014b). Psicose e embriaguez. Psicopatologia fenomenológica da temporalidade. São Paulo, SP: Editora Intermeios. 


\section{OBSERVANDO A PSIQUIATRIA}

Minkowski, E. (2005). Le temps vécu. Études Phénoménologiques et Psychopathologiques. Paris: PUF.

Monti, M. R., \& Stanghellini, G. (1996). Psychopathology: An edgeless razor? Comprehensive Psychiatry, 37(3), 196-204.

Morley, J. (2002, March). Phenomenological and biological psychiatry: Complementary or mutual? Philosophy, Psychiatry, \& Psychology, 9(1), 87-90.

Moreira, V. (2013). Uma perspectiva histórica da psicopatologia fenomenológica. Fenomenologia e Psicologia, 1(1), 123-128.

Parnas, J., Sass, L. \& Zahavi, D. (2011, March). Phenomenology and psychopathology. Philosophy, Psychiatry, \& Psychology, 18(1), 37-39.

Parnas, J., \& Zahavi, D. (2002). The role of phenomenology in psychiatric classification and diagnosis. In M. Maj, W. Gaebel, J. J. Lopez-Ibor, \& N. Sartorius (Eds.), Psychiatric Diagnosis and Classification. World Psychiatric Association Series (pp. 137-162). Chichester, U.K.: John Wiley and Sons.

Parnas, J., Sass, L. A., \& Zahavi, D. (2012). Rediscovering psychopathology: the epistemology and phenomenology of the psychiatric object. Schizophrenia Bulletin, 270-277.

Parnas, J (2014). The RDoC program: Psychiatry without psyche? World psychiatry, 13(1), 46-47.

Pellegrina, H. (2006). Fundamentos antropológicos de la psicopatología. Madrid: Ediciones Polifemo.

Rovaletti, M. L. (2016). ¿Cómo pensar una clínica fenomenológica? VERTEX Rev. Arg. de Psiquiat., XXVII, 47-55.

Schneider K. (2007). Klinische Psychopathologie. Stuttgart-New York: Georg Thieme Verlag.

Stanghellini, G. (2009). The meanings of psychopathology. Current opinion in psychiatry, 22(6), 559-564.

Stanghellini, G., \& Broome, M. R. (2014). Psychopathology as the basic science of psychiatry. The British Journal of Psychiatry, 205, 169-170.

Stanghellini, G., \& Aragona, M. (2016). Phenomenological psychopathology: Toward a person-centered hermeneutic approach in the clinical encounter. In $A n$ Experiential Approach to Psychopathology (pp. 1-43). Springer International Publishing.

Straus, E. W. (1969). Psychiatry and philosophy. In Psychiatry and philosophy (pp. 1-83). Springer Berlin Heidelberg.

Tamelini, M. G., \& Messas, G. P. (2016). On the phenomenology of delusion: the revelation of its aprioristic structures and the consequences for clinical practice. Psicopatologia Fenomenológica Contemporânea 5(1), 1-21. 




Tellenbach, H. (1969). Estudios sobre la patogénesis de las perturbaciones psíquicas. México: FCE.

Tellenbach, H. (1979). La mélancolie. (Trans. L. Claude, D. Saint Macher, A. Sauver, and C. Rogowski). Paris: Presses Universitaires de France.

Zorzanelli, R., Dalgalarrondo, P., \& Banzato C. E. M. (2014, junho). O projeto Research Domain Criteria e o abandono da tradic,ão psicopatológica. Revista Latinoamericana de Psicopatologia Fundamental, 17(2), 328-341.

\section{Resumos}

(Psicopatologia fenomenológica na psiquiatria contemporânea: interface e perspectivas)

Dado o crescente ceticismo em relação ao modelo psiquiátrico dominante atual, a psicopatologia voltou a despertar interesse como ciência. O presente artigo pretende examinar as perspectivas atuais da psicopatologia fenomenológica no cenário da psiquiatria. Para tal, situaremos sua posição no curso histórico da disciplina psicopatologia, apresentaremos as particularidades de seu entendimento de objeto psiquiátrico e, por fim, defenderemos, em linhas gerais, a afinidade da abordagem fenomenológica com as aspirações e as necessidades de natureza prática do campo da psiquiatria.

Palavras-chave: Psicopatologia fenomenológica, psiquiatria, práxis fenomenológica

(Psychopathologie phénoménologique en psychiatrie contemporaine: interface et perspectives)

En raison du scepticisme croissant à l'égard du modèle psychiatrique dominant actuel, l'interêt pour la psychopathologie comme science est en train de ressurgir. L'article qui suit examine les perspectives contemporaines de la psychopathologie phénoménologique dans le domaine de la psychiatrie. Pour ce faire, les auteurs situent la psychopathologie phénoménologique dans l'histoire de la discipline de la psychopathologie, présentent les particularités de sa façon de comprendre l'objet psychiatrique et pour conclure, soutiennent la pertinence de l'approche phénoménologique en ce qui concerne les aspirations et les exigences pratiques du domaine de la psychiatrie.

Mots clés: Psychopathologie phénoménologique, psychiatrie, praxis psychiatrique

(Psicopatología fenomenológica en la psiquiatría contemporánea: interfaz y perspectivas)

Teniendo en cuenta el creciente escepticismo relacionado al modelo psiquiátrico dominante en la actualidad, la psicopatología volvió a despertar interés como ciencia. El presente artículo examina las perspectivas contemporáneas de la psicopatología fenomenológica en el campo psiquiátrico. Para la realización de esta tarea, los autores la ubicarán en el curso histórico de la disciplina psicopatológica, presentarán las particularidades de la comprensión de su objeto psiquiátrico y, finalmente, defenderán la pertinencia del aporte fenomenológico a las aspiraciones y necesidades prácticas de la psiquiatría. 


\section{OBSERVANDO A PSIQUIATRIA}

Palabras clave: Psicopatología psiquiatrica, psiquiatría, praxis psiquiátrica

(Phänomenologische Psychopathologie in der zeitgenössischen Psychiatrie: Schnittstelle und Perspektiven)

Angesichts des wachsenden Skeptizismus in Bezug auf das aktuelle dominante psychiatrische Modell, steigt das Interesse an die Psychopathologie als Wissenschaft erneut an. Der vorliegende Artikel untersucht die aktuellen Perspektiven der phänomenologischen Psychopathologie im Bezug zur zeitgenössischen Psychiatrie. Zu diesem Zweck analysieren wir ihre Situation im historischen Verlauf der Psychopathologie als Disziplin, erläutern wie sie das psychiatrische Objekt definiert und beschreiben abschliessend in generellen Zügen, wie weit die phänomenologische Vorgehensweise den praktischen Bestrebungen und Bedürfnissen der Psychiatrie entgegenkommt.

Schlüsselwörter: Phänomenologische Psychopathologie, Psychiatrie, Phänomenologische Praxis

(现象学-精神病理学在当代心理分析学中的地位: 界面和前景)

由于人们对当前的精神分析学模型的质疑与日俱增, 精神病理学作 为一门科学再次引起了公众的兴趣。本文旨在探讨以现象学方法研究精 神病理学的发展前景。为此, 我们回顾了精神病理学的发展史, 了解精 神病理学对心理分析的独到见解。最后, 我们概括性地论证精神分析学 中的现象学方法与心理分析学领域的理念和实践的协调性。

关键词: 现象学-精神病理学, 精神分析学, 现象学实践

Citação/Citation: Tamelini. M. G., \& Messas, G. P. (2017, março). Phenomenological psychopathology in contemporary psychiatry: interfaces and perspectives. Revista Latinoamericana de Psicopatologia Fundamental, 20(1), 165-180.

Editores do artigo/Editors: Prof. Dr. Claudio E. M. Banzato e Profa. Dra. Rafaela Zorzanelli. 


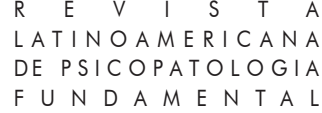

Recebido/Received: 1.3.2017 / 3.1.2017 Aceito/Accepted: 13.3.2017 / 3.13.2017

Copyright: (C) 2009 Associação Universitária de Pesquisa em Psicopatologia Fundamental/ University Association for Research in Fundamental Psychopathology. Este é um artigo de livre acesso, que permite uso irrestrito, distribuição e reprodução em qualquer meio, desde que o autor e a fonte sejam citados / This is an open-access article, which permits unrestricted use, distribution, and reproduction in any medium, provided the original authors and sources are credited.

Financiamento/Funding: Os autores declaram não ter sido financiados ou apoiados / The authors have no support or funding funded to report.

Conflito de interesses/Conflict of interest: Os autores declaram que não há conflito de interesses / The authors have no conflict of interest to declare.

\section{Melissa G. Tamelini}

Instituto de Psiquiatria, Hospital das Clínicas da Faculdade de Medicina da Universidade de São Paulo - USP (São Paulo, SP, Br); Sociedade Brasileira de Psicopatologia Fenômeno-Estrutural - SBPFE (São Paulo, SP, Br).

Rua Haddock Lobo, 846/205 - Torre Beta

01414-000 São Paulo, SP, Br

melissa.tamelini@hc.fm.usp.br

\section{Guilherme P. Messas}

Coordenador do Programa de Psicopatologia Fenomenológica da Faculdade de Ciências Médicas da Santa Casa de São Paulo (São Paulo, SP, Br).

Sociedade Brasileira de Psicopatologia Fenomenológica - SBPFE

Rua Joaquim Floriano, 871/121

04534-013 São Paulo, SP, Br

guilherme.messas@fcmsantacasasp.edu.br

This is an open-access article, which permits unrestricted use, distribution, and reproduction in any medium for non-commercial purposes provided the original authors and sources are credited. 